\title{
THE RECEPTION OF THE ALLEGORICAL POEM THE THREE GYPSIES BY NIKOLAUS LENAU IN THE FINE ARTS DURING THE NINETEENTH CENTURY
}

\begin{abstract}
Roma people are often depicted in Central European literature and fine arts in the end of the eighteenth century and the first half of the nineteenth century. The topic was likely chosen not only because of an ethnographical interest, but also because orientalism in the nineteenth century meant for several Austrian artists the depiction of the life and customs of Hungarian and Transylvanian gypsies, who were believed to be originally from the East. In the second half of the century August Pettenkofen, who had often visited the town of Szolnok in the Great Hungarian Plain with his painter friends, also turned to the 'exotic' life of Hungarian peasants, csikós (horse-herdsmen) and nomadic gypsies. The artists of genre artworks depicting the folk, a genre flourishing in Hungary since the middle of the nineteenth century, also often choose the life and customs of Roma people as the topic of their art, usually presenting them in a detailed way and using stereotypes.

This study examines a different kind of depiction of Roma people in the nineteenth century in literature, artworks and music. The so-called 'Three gypsies' topic is currently believed to have appeared for the first time in 1836 in Ferenc Pongrácz's painting, however, it became truly popular because of Nikolaus Lenau's poem, which had a title similar to the painting's and was published soon after the painting. The topic appears in several contemporary paintings and illustrations, and Ferenc Liszt also created a musical composition based on it. Lenau's poem and the artworks inspired by it include a certain symbolical-philosophical approach instead of the ethnographic interest popular at the time or the anecdotical depiction of the everyday life of Roma people. The image of the three gypsies in the poem and the artworks and illustrations - the first one is playing a fiddle, the second one is smoking a pipe and the third one is sleeping - symbolizes not only the longing for a poor but free life without the yoke of social norms, but also illustrates different attitudes and philosophies of life (vita activa, vita contemplativa, turning away from the world).

The symbolical-philosophical nature of the poem and the artworks is emphasized by a significant part of these works, the motif of the instrument hung upon a tree, which first appears in Psalm 137 from the Old Testament. The psalm depicts the pain of the Jews suffering in the Babylonian captivity, who in their sorrow hung their harps upon the willows. The song about the sadness felt because of their exile and the loss of their home was later interpreted in the context of those times. The heartbreaking description of the destroyed home of the exiled Jews in János Thordai's psalm written in the seventeenth century was likely inspired by the grief caused by the destruction of Hungary during the Ottoman rule. The motif of the instruments hung upon the tree, earlier related to society and nation, was enriched with new, individualistic meanings during the end of the eighteenth and the beginning of the nineteenth century.

The depictions of the atypical Three gypsies topic in literature and fine arts are more closely related to allegorical paintings from earlier centuries, for example Giorgone's The Three Philosophers or The Three Ages of Man, than to the genre artworks in the nineteenth century depicting the life of Roma people in an anecdotal way.
\end{abstract}

Keywords: Nikolaus Lenau, Roma people in Central European literature and fine arts

The tradition of depicting Romani people in European art is several centuries old: they appear in the works

\footnotetext{
* Júlia Papp PhD, Budapest, Institute of Art History, Research Centre for the Humanities, Hungarian Academy of Sciences; email: papp.julia@btk.mta.hu
}

of, for example, Hieronymus Bosch, Pieter Bruegel the Elder, Giorgione and Jacques Callot. ${ }^{1}$ From the end of the eighteenth century, Romani people started to be depicted on printed graphics series, which were becoming more and more popular in the multinational Habsburg Empire. These series were illustrations of outfits and professions (Kaufruf, in German) as well as dif- 
ferent nationalities and ethnicities. ${ }^{2}$ One of the depictions of Romani musicians was the engraving series of excellent quality created at the end of the 1770s by Johann Martin Stock (1742-1800), ${ }^{3}$ who was born in Nagyszeben (Hermannstadt, Sibiu, today Romania) in Transylvania and received academic education. The Romani people, just like the representatives of other ethnicities, were also included in the most important Hungarian and Transylvanian costume picture series (created for example by József Bikessy-Heimbucher and Franz Neuhauser [1763-1836]) from the beginning of the nineteenth century. ${ }^{4}$ 'In the printed graphics published in Hungary, the Romani people were the objects of scholarly studies, and they were considered to be equal with other ethnic groups as a category of people and a social minority, not included in the concept of nationality but undoubtedly part of the concept of ethnicity. For the first time - and we can say that for the last time till this day - they became a topic of Hungarian artworks without even a trace of the first sentimental, then sarcastic and condescending tones typical of later public opinions, discussions and literature. ${ }^{5}$

The motif of the gypsy was popular partly because at the end of the eighteenth century and the beginning of the nineteenth century orientalism for many Austrian and German painters meant not only the artistic depictions of their experiences during their travels in the geographically 'real' East, but it also included the life and customs of the Roma people, who were believed to be of eastern origin. However, during the nineteenth century the depiction of Romani people in artworks started to include specific allegorical and symbolical meanings as well. Because of their strangeness, exoticness and status as the outsiders of society they symbolized the free and autonomous life for the bourgeois who could not violate the norms of civilization. ${ }^{6}$ One way of depicting this longing was using the motif of the so-called 'three gypsies', which, based on Nikolaus Lenau's poem, became very popular in the nineteenth century in artworks, music and literature alike. ${ }^{7}$

According to current studies, the first appearance of the motif can be dated before Lenau's poem was written. The Hungarian artist Ferenc Pongrácz made a small $(42 \times 34 \mathrm{~cm})$ oil painting titled Gypsy Playing a Fiddle in 1836, which is currently exhibited in the Hungarian National Gallery. The artwork depicts three Roma men around a willow: the first one is playing a fiddle, the second one is smoking a pipe and the third one is sleeping. A tambourine is hung upon one of the branches of the tree (Fig. 1). ${ }^{8}$

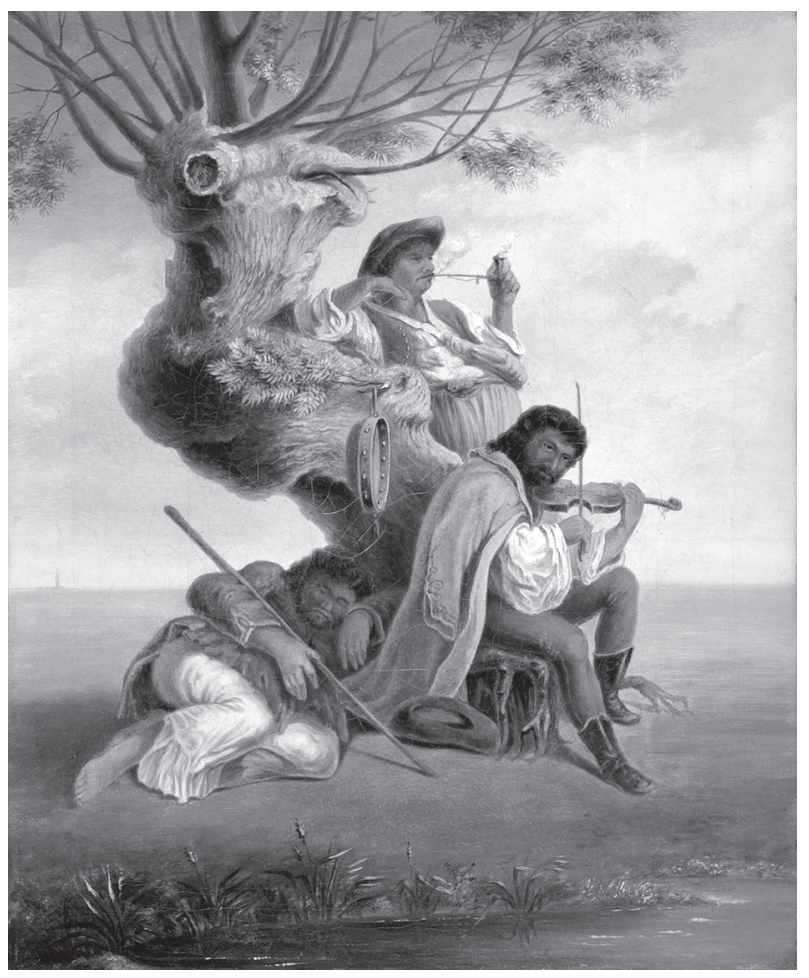

Fig. 1. Ferenc Pongrácz: Gypsy Playing a Fiddle, oil on canvas, 1836; Budapest, MNG

An exact description of this scene is written in a poem by Nikolaus Lenau ( $\mathrm{N}$. Niembsch von Strehlenau, 1802-1850). Lenau, born in Csatád (Lenauheim) in Temes (Timiş) County in Hungary (today Romania), was an Austrian poet who spent his childhood near Tokaj (Hungary). The poem titled The Three Gypsies ('Die drei Zigeuner') has a Hungarian theme and was written either before the end of October 1837 or between January and March $1838 .^{9}$

\section{The Three Gypsies}

Three Gypsies I found once

lying by a willow,

as my cart with weary torture

crawled over the sandy heath.

One, for himself alone, was holding

his fiddle in his hands,

playing, as the sunset glow surrounded him, a merry little tune.

The second held a pipe in his mouth and watched his smoke with cheer, as if from the world he required nothing more for his happiness. 
And the third slept comfortably: from the tree hung his cymbalom; over its strings the wind's breath ran; in his heart a dream was playing.

On the clothing those three wore were holes and colorful patches; but, defiantly free, they made a mockery of earthly fate.

Trebly they showed me how, when life grows dark for us, one can smoke, sleep or play it away, and thus trebly to scorn it.

At the Gypsies, longer yet I had to gaze in passing, at their dark brown faces, at their black-locked hair.

The connection between Ferenc Pongrácz's painting and Lenau's poem has yet to be cleared up. György Rózsa, who wrote the catalogue of a travelling exhibition of Lenau's works organized in 1995 in the Hungarian National Széchényi Library, ${ }^{10}$ thought that Pongrácz's painting inspired Lenau to write his wellknown poem. Ágnes Watzatka agrees with this theory in her paper published in 2014. According to her, Lenau could have seen the reproduction of the painting in a Viennese literary magazine, which inspired him to write his poem, and he interpreted the scene using his own experiences and feelings. ${ }^{11}$ Marianna Oros-Klementisz also believes that Pongrácz's painting was an inspiration for Lenau. In Vienna Lenau could have seen either a reproduction of the painting or the original artwork, or perhaps a sketch of the original painting. ${ }^{12}$

Though this is of course possible, it is more likely that - as also mentioned by György Rózsa - both the painting and the poem were inspired by an earlier literary work or artwork (in the latter case maybe an illustration in an Austrian or German almanac). Both the poem and the artworks - which, as we will see later, have several versions, but they are all closely related to each other and the poem - have a mature composition and they are more than simply a genre scene (which were popular at the time): they have philosophical and allegorical meanings as well. It is possible that Ferenc Pongrácz, who was not considered to be a significant painter even by his contemporaries, was not prepared to create a painting with such complex meaning and mature composition on his own, without being inspired by any earlier artwork or literature.

Either way, it is certain that the lithograph illustrating the Hungarian translation of Lenau's poem The Three Gypsies, translated by Kálmán Thaly and published in the newspaper called Az Ország Tükre in $1865^{13}$ (Fig. 2), was based on Pongrácz's painting. Pongrácz's painting and Lenau's poem were undoubtedly already connected then. There are only small differences between the painting and the illustration: the creator of the lithograph ${ }^{14}$ changed a few details to make the illustration fit the poem more. On Pongrácz's painting, the instrument hung upon the tree is a tambourine, but on the lithograph it is a cymbalom, like in the poem: 'Und sein Zimbal am Baum hing'. We can see on the background of the lithograph the cart on which the poet is travelling, turning back to look at a group of Roma people - an exact illustration of the frame story of the poem: travelling through the plains.

Another version of the motif of the three gypsies in fine arts is the painting by Rudolf Swoboda, an Austrian landscape and animal painter. The painting titled The Three Gypsies $(88 \times 105 \mathrm{~cm}),{ }^{15}$ now exhibited in the Wien Museum in Vienna, was painted around 1850, inspired by Lenau's poem. Though the picture seems to be distantly related to Pongrácz's painting,

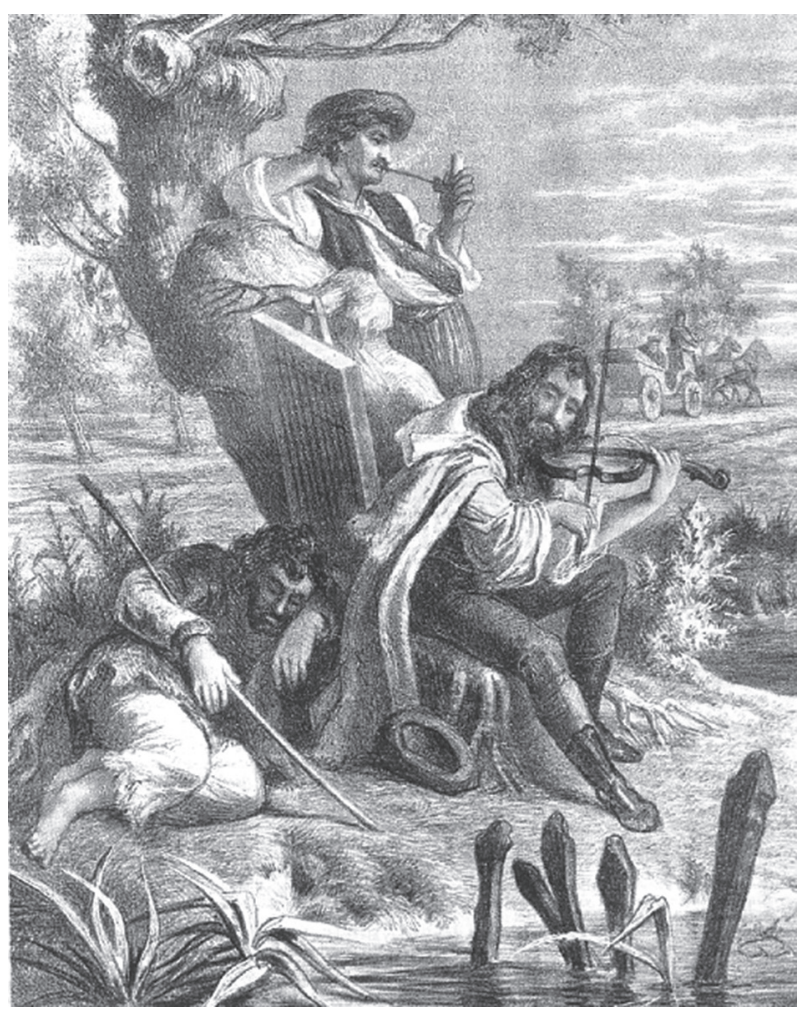

Fig. 2. The Three Gypsies, lithography; from: Az Ország Tükre 1865/30. 345. 
mainly because of the depiction of the willow, there are also several differences: Swoboda's painting is not vertical, but horizontal, the three Roma men are all sitting under the tree and a cymbalom - unlike on Pongrácz's painting but similarly to the poem - is hung on the tree.

The composition of an oil painting in a private collection in Budapest ${ }^{16}$ (Fig. 3) is much closer to Ferenc Pongrácz's picture, though there are some differences between the two images. On Pongrácz's painting and the lithograph based on it, which was created in 1865, the man standing next to the willow is smoking a pipe and the sitting man is playing a fiddle, while on this picture their positions are changed: the sitting man is smoking the pipe and the standing man is playing the fiddle. The posture of the lying man is different too, and he - unlike on Pongrácz's painting - does not have a staff in his hand. On Pongrácz's painting a tambourine is hung upon the tree, but here - like in the poem - the instrument is a cymbalom. However, despite these differences the theme of the pictures is the same, and their composition is very similar as well (for example the position of the figures and the tree, the details of the canopy of the tree), and these images can undoubtedly be considered variations on a theme. The paintings were parts of the exhibition titled ROMAESINTI 'Zigeuner-Darstellungen' der Moderne, organized in the Kunsthalle in Krems in 2007. ${ }^{17}$ They also appeared in the exhibition organized in the Museum of Ethnography in Budapest in 2011, titled Ferenc Liszt and the 'Gypsy Music'.18

A colored lithograph created in Vienna in 1859 (Fig. 4) has a signature which reveals not only the direct relationship between the composition found in the private collection and Lenau's poem, but also the identity of the artist. 'Die Drei Zigeuner / nach Lenau's gleichnamigen Gedichte. / von dem oesterreichischen Kunst-Vereine zu Wien 1859. Gemalt u. lith. v. A. Schönn - Eigenthum des oesterreichischen Kunstverein's - Druck v. Reiffenstein \& Rösch in Wien.'19 is written under the lithograph, which means that the picture was painted and lithographed ('gemalt und litografiert') by Alois Schönn (1826-1897), based on Lenau's poem and commissioned by the Austrian Artists' Society. 'Die drei Zigeuner' nach Lenau's Gedicht (500 fl.), gek. von. H. Mertens. ${ }^{20}$ - which means that the original painting was bought by Mister Mertens for 500 forint - is also written in Constant von Wurzbach's biographical lexicon in the list of the artworks created in 1859 by Alois Schönn, the excellent Austrian veduta painter fond of exotic oriental themes. ${ }^{21}$

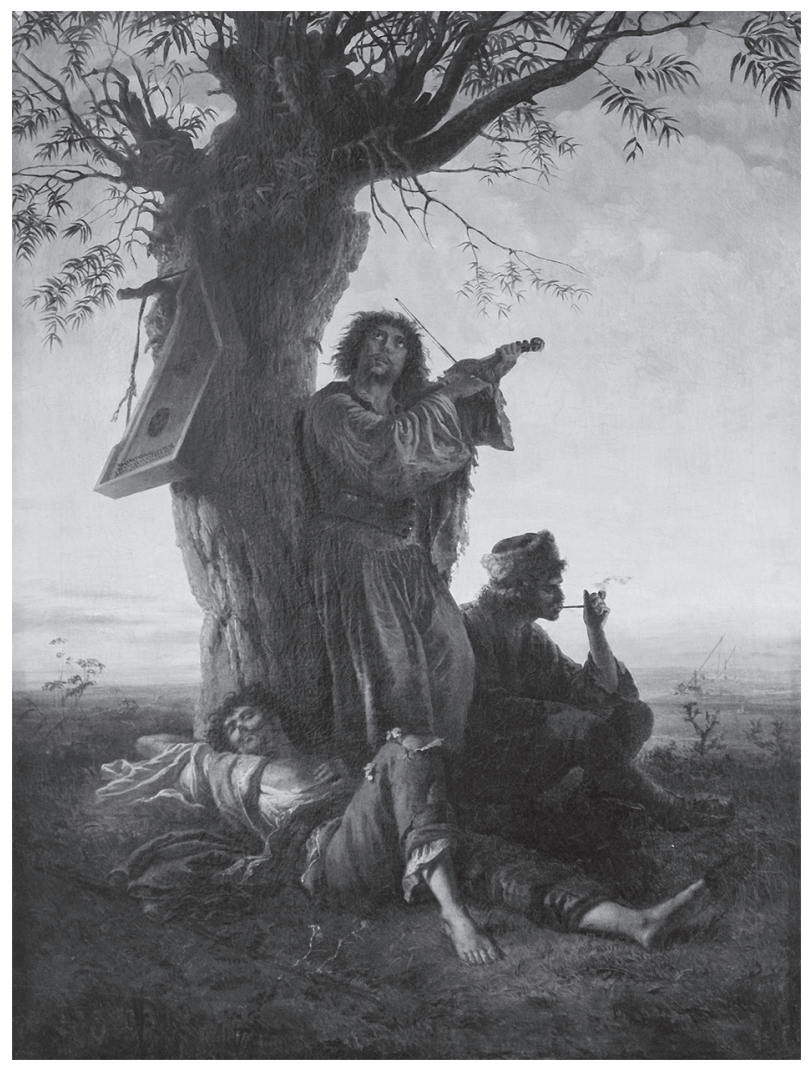

Fig. 3. Alois Schönn (?): The Three Gypsies, oil on canvas, 1859 (?); private collection (Budapest, Nagyházi Gallery and Auction House)

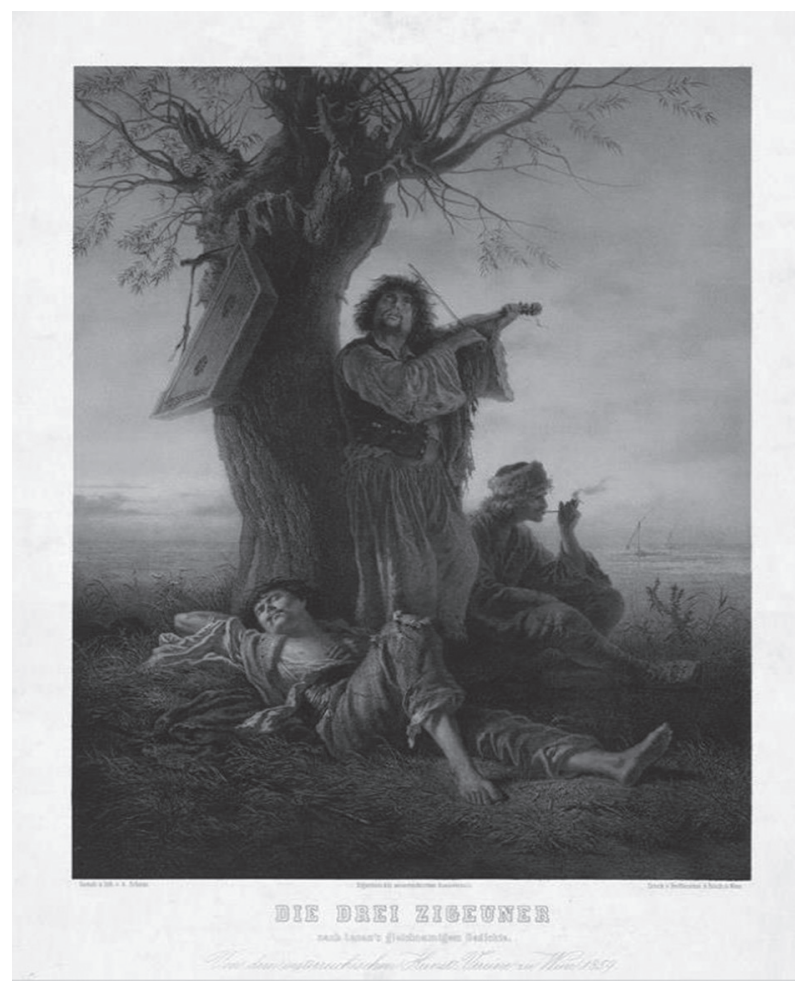

Fig. 4. Alois Schönn: The Three Gypsies, lithography, 1859 
Schönn ${ }^{22}$ was a student of Leander Russ (18091864), and he studied historical painting at the academy in Vienna between 1845 and 1848 in Joseph von Führich's (1800-1876) class. Paintings of battles and genre scenes ${ }^{23}$ depicting the events of 1848 and 1849 were his first achievements. After studying in Paris (1850-1851), he travelled to the East (Turkey, Egypt, Tunisia), and later visited Italy, Galicia and other countries in the Balkans. His art, which combined portrayals of anecdotical scenes and the depictions of the characteristics of exotic lands and people, was recognized by the academy in the second half of the nineteenth century: he won several royal and institutional Austrian and foreign awards, ${ }^{24}$ became a member of the academy in Vienna and received the title of professor. His paintings are exhibited in museums in Vienna (Historisches Museum der Stadt Wien, Gemäldegalerie der Akademie der bildenden Künste, Österreichische Galerie) and in Austrian provinces (Graz, Landesmuseum Joanneum; Innsbruck, Ferdinandeum; Troppau, Museum). His six large murals (1882-1889), which depict for example the Buddha statue of Kamakura (Japan), a Maori village or a camp of Australian aboriginals, decorate the walls of the exhibition rooms of the anthropology and mineral collections of the Naturhistorisches Museum in Vienna on the mezzanine floor.

Schönn's Hungarian connections are also well known. During the Hungarian Revolution and War of Independence in 1848-1849 he was accused of being a spy and imprisoned by Hungarian soldiers near Komárom. The Austrian army saved him from being executed after they captured the fortress. Similarly to The Three Gypsies painting, a lithograph was created of another one of his artworks, which depicted a scene from the Hungarian Revolution and War of Independence: A Hungarian Family Returning Home (Fig. 5). ${ }^{25}$ During his travels in 1856 in Hungary and Transylvania he mostly painted genre artworks of markets and Roma people. ${ }^{26}$ His oil painting titled Lagernde Zigeuner (Resting Gypsies) $(94,5 \times 127,5 \mathrm{~cm})$ was likely also created in 1856 as part of this series (Fig. 6). ${ }^{27}$

The life of the Roma people was one of Schönn's favorite topics. In public exhibitions in 1857, for example, all five of his artworks depicted this theme: 'Zigeunerlager' (500 fl.), in der Gallerie des Herzogs von Coburg; - 'Zigeunerknabe aus Siebenbürgen' (150 fl.); - 'Zigeunermädchen aus Siebenbürgen' (150 fl.); - 'Zigeunerfamilie' (150 fl.) - 'Lagernde Zigeuner' (200 fl.), in der Gallerie des Herzogs von Coburg. ${ }^{28}$

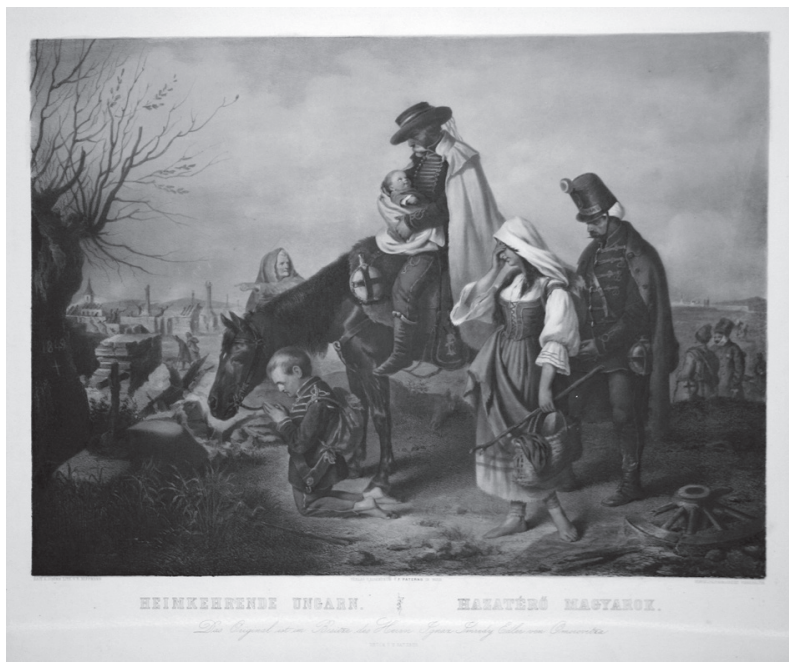

Fig. 5. Alois Schönn - R. Hoffmann: Heimkehrende Ungarn, lithography, 1859; Budapest, MNM

His colored lithograph of the orthodox church in Gyalu (Gilău, today Romania) and his watercolor painting of the peasant houses in Gyalu are part of the collection of the Hungarian National Museum. ${ }^{29}$ During 1855 and 1856 he worked in Vienna on the lithographs of Károly Lajos Libay's (1816-1888) album titled Reisebilder aus dem Orient, which depicted Libay's travels in Egypt and Nubia. ${ }^{30}$

The composition of the oil painting now in a private collection in Budapest is the same as the composition of the lithograph created for Lenau's The Three Gypsies poem, which, according to the signature, was 'painted and lithographed' by Alois Schönn. Though the quality of the oil painting is so excellent it is easy to believe that it is Schönn's work, the history of the picture makes the attribution uncertain. According to the Austrian literature, Alois Schönn's The Three Gypsies picture painted in 1859 was taken to America. Maybe the painting was later taken back to Europe ${ }^{31}$ perhaps by an art collector who was a fan of Lenau, but it is also a possibility that the picture in Hungary is a reproduction of Schönn's original artwork. Schönn created several versions of the painting. An oil on cardboard painting $(60,5 \times 48 \mathrm{~cm})$ titled Rastende Zigeuner (Resting Gypsies), signed by Schönn (Fig. 7), was auctioned in the Dorotheum (Vienna) on October 16, 2013. The composition of this painting is almost exactly the same as the composition of the picture in Budapest and the lithograph of Schönn's painting, the only difference is the position of the head and the direction of the gaze of the Roma man smoking the pipe. ${ }^{32}$

Schönn's painting - or the lithograph based on it, which was distributed widely - must have been popu- 


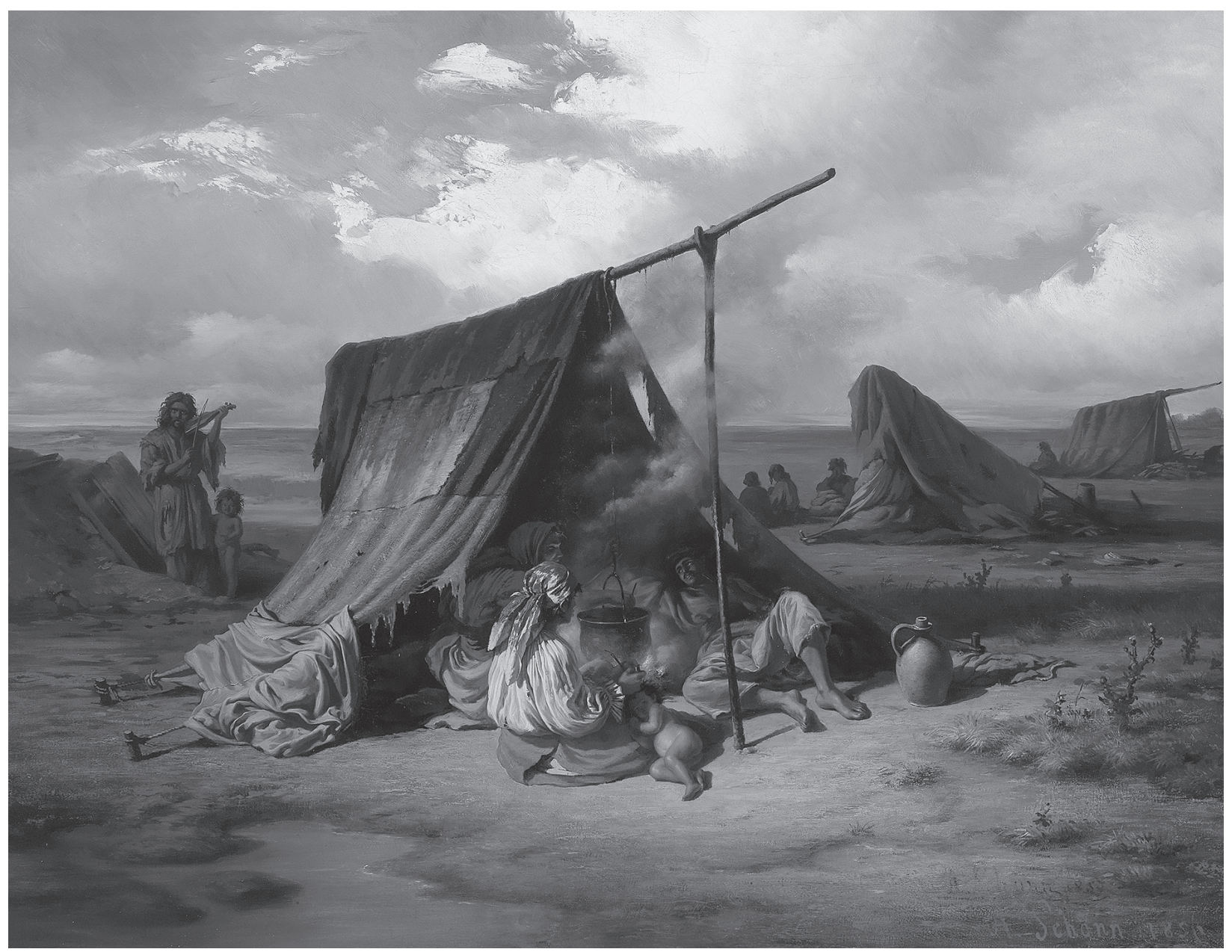

Fig. 6. Alois Schönn: Lagernde Zigeuner, oil on canvas, 1856; private collection

lar in Hungary too, as shown by the reproductions of the composition likely created in Hungary. According to a black and white photograph in the Documentation Department of the Hungarian National Gallery (B 372/977) a small oil painting of poor quality was examined in 1977, which was a copy of Schönn's painting. A reproduction of Alois Schönn's painting was sold with the title The Rest of the Shepherds in 2001. ${ }^{33}$ A painting titled The Rest of the Musicians $(68 \times 55 \mathrm{~cm})$ from the nineteenth century, based also on Schönn's composition and without a signature, was part of an auction (item 15) of the Nagyházi Gallery in April 12, 2011.34

I have found no information about whether Alois Schönn could have seen Ferenc Pongrácz's painting, created more than two decades earlier, however, similarities in composition and approach between the two paintings make it likely that there is a direct connection which, just like the relationship between Pongrácz's painting and Lenau's poem, has yet to be verified.
Scholars date Pál Szinyei Merse's (1845-1920) 'only charcoal drawing with a Hungarian folk theme' to $1865,{ }^{35}$ which - probably inspired by the earlier mentioned illustration published in the Az Ország Tükre depicts The Three Gypsies (Fig. 8). The topic found on page 17 of Szinyei's second sketchbook was later painted on a separate, larger paper. This wash drawing is exhibited today in the museum of the city of Sabinov in Slovakia (Fig. 9). ${ }^{36}$ It seems that Szinyei must have seen the illustrations of both Pongrácz's and Schönn's painting, because the placement of the characters in the two drawings borrows from the composition of the two paintings. Pál Böhm's (1839-1905) illustration of Lenau's poem, titled Three Gypsies, was published in a newspaper called Über Land und Meer in Stuttgart in 1895 (Fig. 10). The German illustrator Ferdinand Rothbart was likely inspired by Ferenc Pongrácz's painting when he created a steel engraving illustrating Lenau's poem in the second half of the nineteenth century.

Lenau's poem was also put to music by Ferenc Liszt (1811-1886) in 1860. Liszt owned a lithograph 


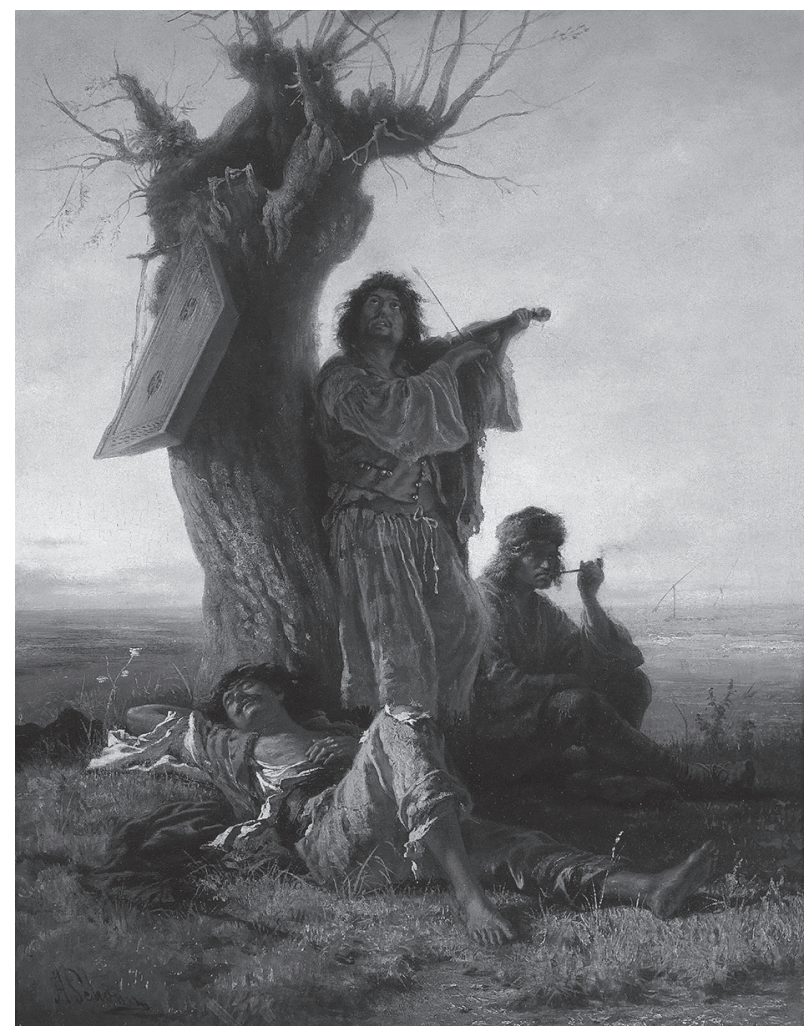

Fig. 7. Alois Schönn: Rastende Zigeuner, oil on cardboard, circa 1860; private collection

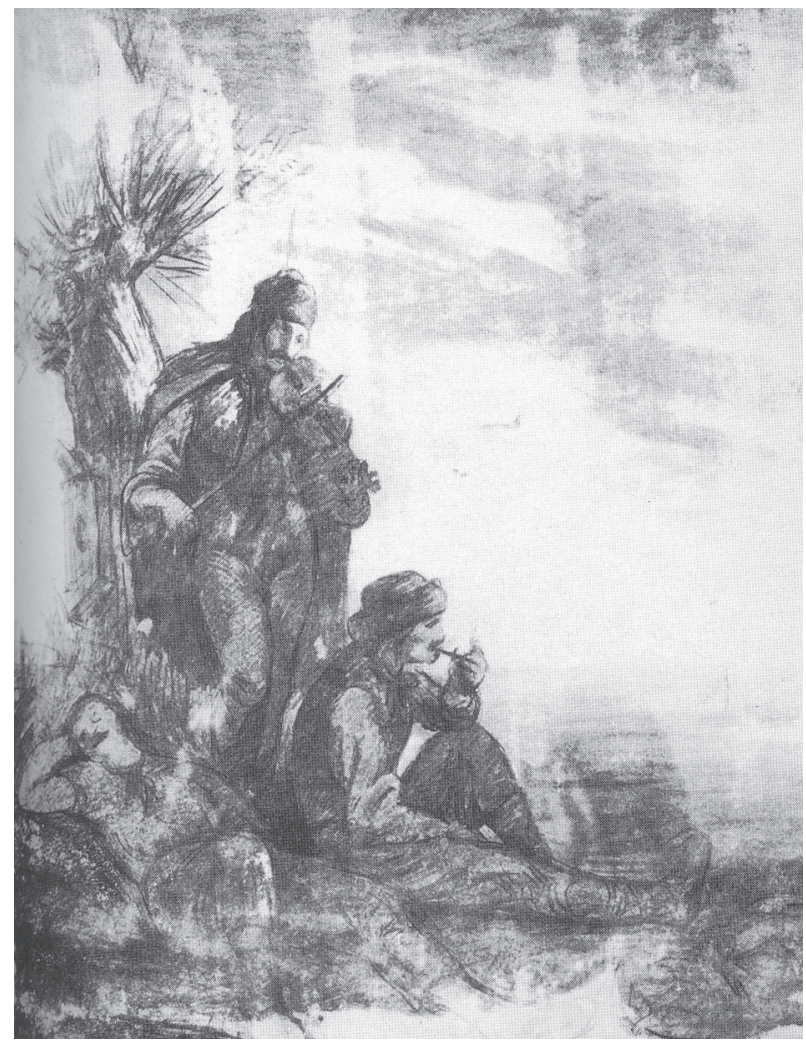

Fig. 8. Pál Szinyei Merse: The Three Gypsies, charcoal drawing, circa 1865; Budapest, MNG of Schönn's painting, found today in the Liszt Ferenc Memorial Museum and Research Centre in Budapest.

The motif of the instrument hung upon the tree appears both in the paintings and the poem. An earlier depiction of the motif appears in the passionate, dramatic Psalm 137,37 which can be considered a jeremiad. Recently, there has been a growing interest among scholars in the reception of the psalms of the Old Testament not only in exegesis and religious studies, ${ }^{38}$ but - related to and occasionally intertwined with the study of tropes - in Hungarian literary history as well. ${ }^{39}$ The study of the reception of psalms - as illustrated by our current topic - is also important for those who study motifs. ${ }^{40}$

Psalm 137: By the Rivers of Babylon (Ezekiel 1:1-3)

By the rivers of Babylon we sat and wept when we remembered Zion.

There on the poplars we hung our harps, for there our captors asked us for songs, our tormentors demanded songs of joy; they said, 'Sing us one of the songs of Zion!'

How can we sing the songs of the LORD while in a foreign land? If I forget you, Jerusalem, may my right hand forget its skill.

May my tongue cling to the roof of my mouth if I do not remember you, if I do not consider Jerusalem my highest joy.

Remember, LORD, what the Edomites did on the day Jerusalem fell.

'Tear it down,' they cried, 'tear it down to its foundations!' Daughter Babylon, doomed to destruction, happy is the one who repays you according to what you have done to us. Happy is the one who seizes your infants and dashes them against the rocks.

The poetic image at the beginning of the psalm - the Jews suffering in a foreign land use the defiant silence of their instruments to protest the blasphemous, cynical order of the captors and to express the sorrow they feel because of their exile, the longing to be free and 
the sadness, pain and grief they have to endure because of the loss of their home ${ }^{41}$ - has remained a part of the interpretations and translations for a long time.

This original meaning was conveyed in the copper engraving titled Die trauernden Juden (Sorrowful Jews) from the nineteenth century, signed 'Bindemann pinxit, A. Duttenhofer s.c.' (Fig. 11), ${ }^{42}$ which depicts a sad Jewish man in shackles, women and a child sitting under an enormous tree on the riverbank with the metropolis of Babylon in the background. Though the harp in this picture is not hung upon the tree, but held in the hand of the dispirited man, lowered to the ground, the silence of the instruments in this artwork also symbolizes the grief and pain of the community.

However, the original meaning of the psalm, similarly to other psalms, had been occasionally enriched with new meanings related to the context of later times. ${ }^{43}$ These literary works, becoming increasingly more mature and polished during the centuries, are exceptionally well-suited for generalizations and adaptations: people living in different eras are able to find analogies for their own beliefs, feelings, worldviews, joys and sorrows in them. For example, the heartbreaking description of the destroyed home of the exiled Jews in János Thordai's psalm written in the seventeenth century, more detailed than in the original text, was undoubtedly inspired by the sadness felt

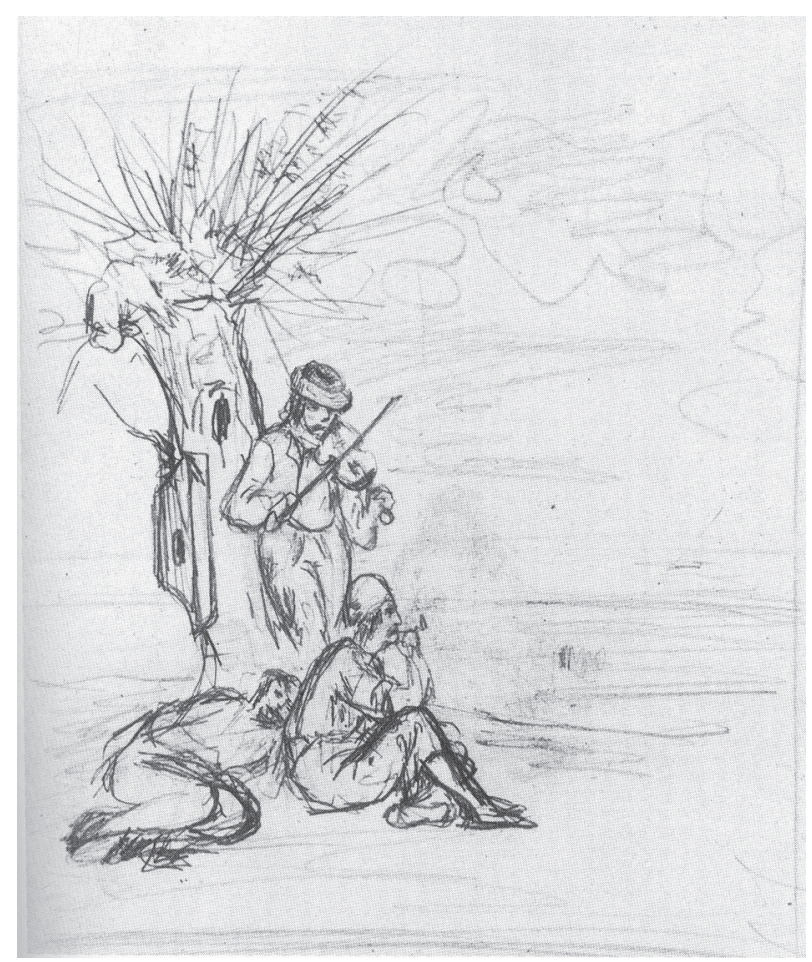

Fig. 9. Pál Szinyei Merse: The Three Gypsies, wash drawing, circa 1865; Sabinov (SK), Metské museum because of the destitution and destruction of Hungary during the Ottoman rule. ${ }^{44}$

During the end of the eighteenth century and the beginning of the nineteenth century this motif was enriched with new, individualistic content, added to the earlier meanings related to the entire community. In some literary works the instrument hung upon the tree, symbolizing the poet falling silent, was used to illustrate the inability of the outside world to understand the poet or the poet's inner artistic crisis. In Mihály Csokonai Vitéz's (1773-1805) poem about saying goodbye to his lute written in 1795 - similarly to his poem titled Farewell to the Hungarian Muses - he uses a bitter, ironic tone to write about his realization that it is impossible to fulfill his vocation as a poet and his literary plans: ${ }^{45}$

I swear on the ruined altar of Apollo, even on the words of all the muses, that I will hang you upon the elder tree for the last time. ${ }^{46}$

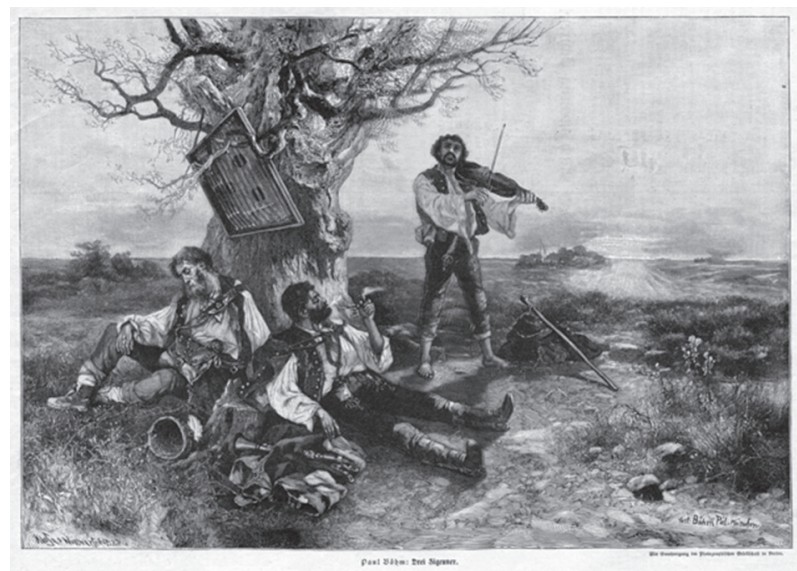

Fig. 10. Pál Böhm: The Three Gypsies, lithography, 1895

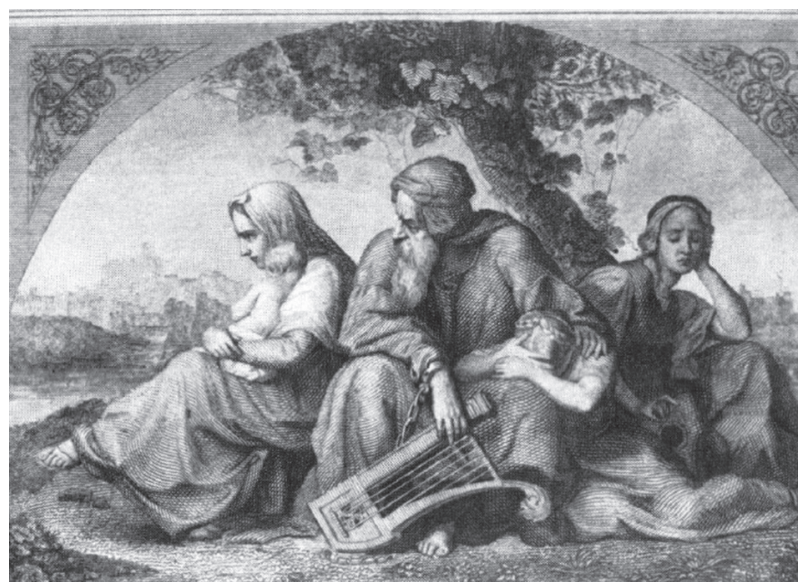

Fig. 11. Bindemann-Duttenhofer: Die trauernden Juden, engraving, nineteenth century 
The ending of András Farkas's (1770-1832) poem about a poet saying goodbye to his quill and the illustration of the poem was created in a similar situation and conveyed a similar meaning:

So - if no one respects the poets anymore,

I will hang my fiddle upon the weeping willow. ${ }^{47}$

The last lines, which refer partly to exile - just like the engraving illustration added to the poem, depicting the poet hanging his fiddle upon the weeping willow in a naive style similar in tone to folk art - are obvious references to Psalm 137 (Fig. 12).

Psalm 137 was also a favorite of Endre Ady (18771919). The motif in his life and poetry mainly seems to have an individualistic meaning. In his poem titled On the Shore of Dark Waters he writes:

I was sitting on the shores of Babylon,

and I had already sat on the shores of Worry...

I had hung my harp,

I had unhang my harp. ${ }^{48}$

In his poem titled The Psalm of the Mammon Monk he writes:

Sitting by the dark waters of Babylon,

I hang my harp upon the sacred, weeping willow. ${ }^{49}$

Both poems are the personal lament of the poet, talking about his disappointments and his struggle with money, life and art. 'The psalm, the lamentation of the Jews suffering in Babylonian captivity was very fitting for the mood of the weary poet. ${ }^{50}$

One of the references to Psalm 137 is the willow, ${ }^{51}$ which appears both in the psalm from the Old Testament and the poem, paintings and the lithograph. On Ferenc Pongrácz's painting and the lithograph based on it created in 1865 we can see a brook or river with sedge in front of the willow, which can be an allusion to the biblical scene by the river of Babylon.

Even though genre artworks depicting the life of the different nationalities and ethnic groups of the Habsburg Empire - including the Roma people - became increasingly more popular during the Biedermeier period, Ferenc Pongrácz's and later Alois Schönn's painting and Lenau's poem were not traditional genre works: they had a specific allegorical-symbolical and philosophical meaning as well. Miklós Barabás (1810-1898), for

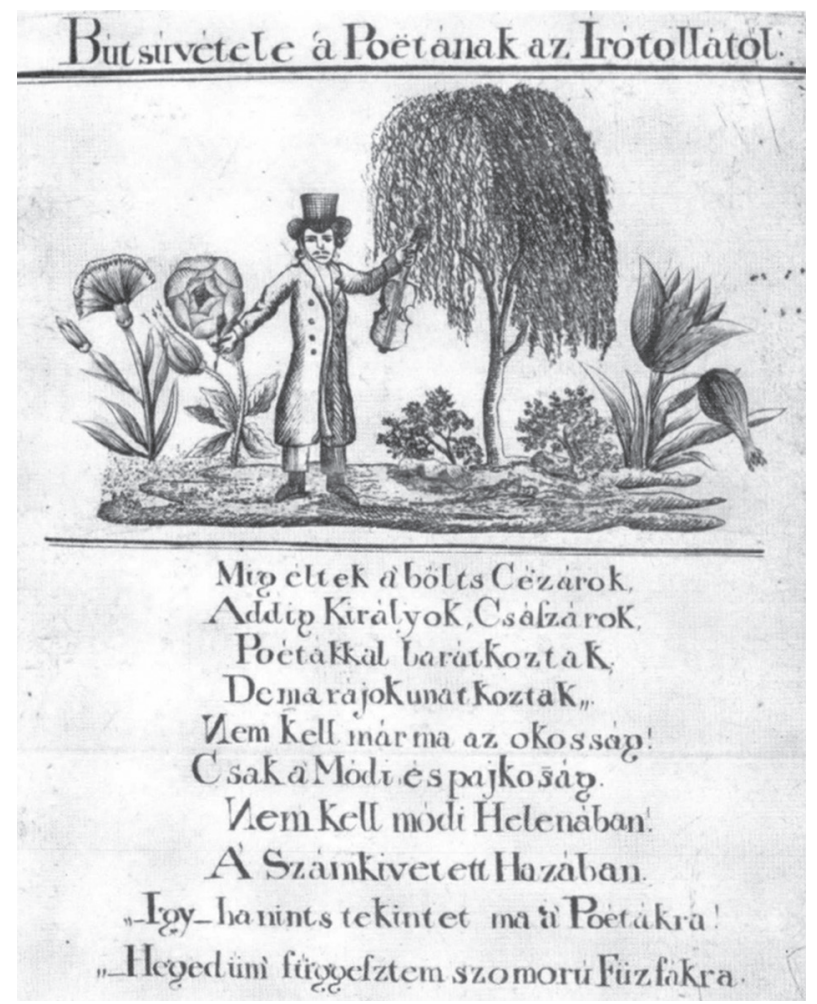

Fig. 12. The Poet's Farewell from the Poetry, illustration, engraving, 1829

example, has several paintings of traditional genre scenes with many characters and details, which include anecdotic and humorous elements. One of them is titled Wandering Gypsy Family in Transylvania, painted in 1843 (Fig. 13), which was presented in the spring exhibition in Vienna, but the painting was not successful because the visitors expected more refined artworks. ${ }^{52}$ Sándor Petôfi (1823-1849), however, wrote a long poem about the painting in April 1844 titled A Life of Wandering. Based on Barabás's Drawing. Another such painting was Barabás's picture titled Wandering Gypsies, painted in 1846 - a colored lithograph of this painting was included in Gábor Prónai's album of sketches illustrating the life of the people living in Hungary, published in 1855 in Pest (Fig. 14). ${ }^{53}$ Alois Schönn's earlier mentioned picture titled Lagernde Zigeuner (1856) (Fig. 6) has a similar composition. These paintings give the appearance of being genre scenes inspired by direct, concrete experiences, even though they use tropes and iconographic elements related to the Roma people: a smoking old woman, men playing a fiddle, blacksmiths and tinkers, women reading palms and carrying saleable tubs, naked children, half-naked girls, ragged tents, et cetera. ${ }^{54}$

Pongrácz's and Schönn's atypical paintings based on the poem The Three Gypsies are much more similar 


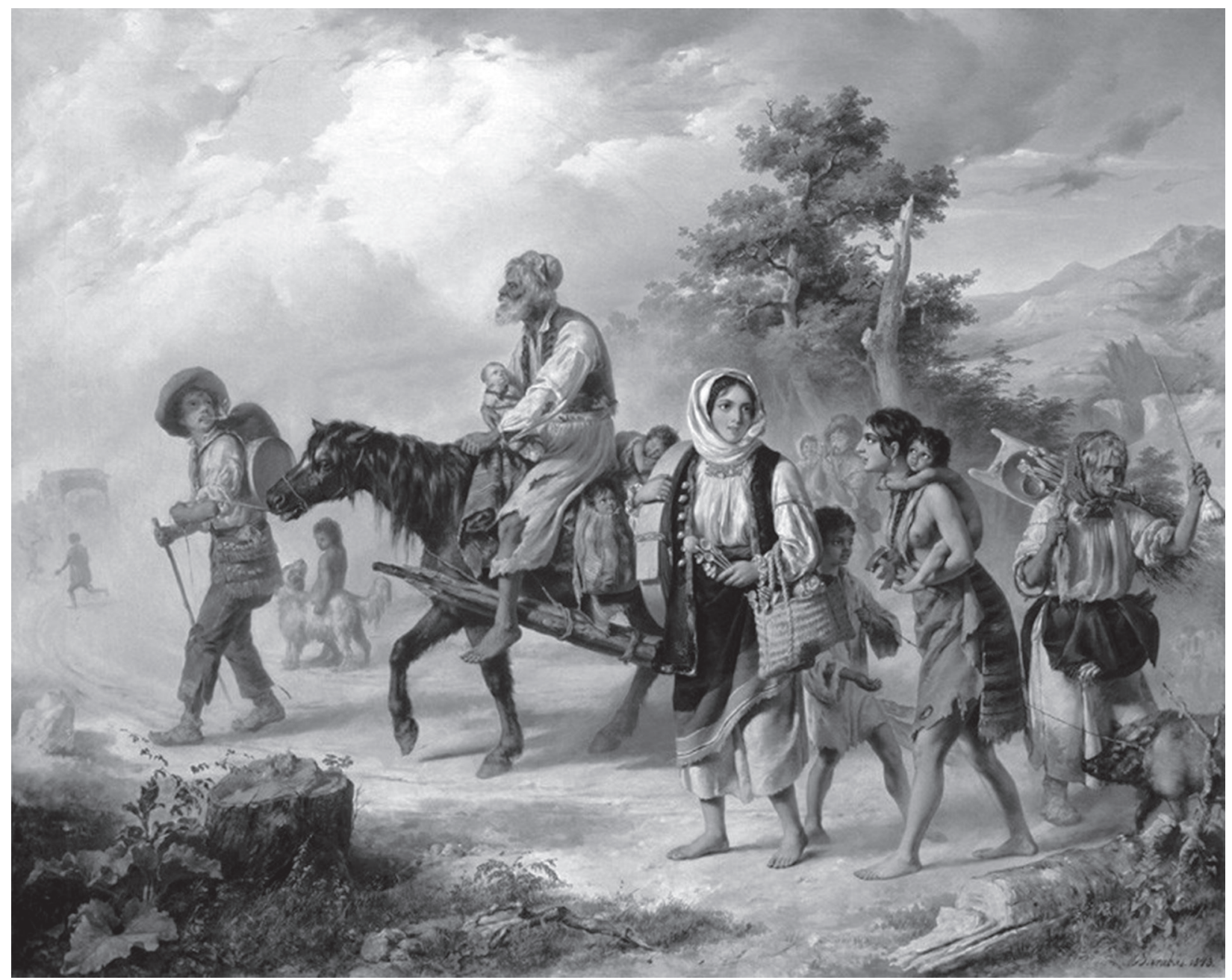

Fig. 13. Miklós Barabás: Wandering Gypsy Family in Transylvania, oil on canvas, 1843; Budapest, collection of the MKB Bank

both in approach and in composition to the allegorical paintings of earlier centuries, for example Giorgione's The Three Philosophers ${ }^{55}$ (Fig. 15) or The Three Ages of Man ${ }^{56}$ (Fig. 16), than to these genre paintings. Pongrácz's and Schönn's paintings - just like Lenau's poem - present different attitudes or philosophies of life: the man playing the fiddle represents active life (vita activa), the man smoking the pipe contemplative life (vita contemplativa) and the sleeping man symbolizes the possibility of turning away from the world. They can also illustrate one of the important meanings of Lenau's poem: Roma people, even though they live in poverty, symbolize freedom for the poet, who is forced to become part of society and is suffering under this exhausting yoke.

On the clothing those three wore were holes and colorful patches; but, defiantly free, they made a mockery of earthly fate.
This independence and freedom is also symbolized on Pongrácz's and Schönn's paintings by the fact that they do not depict the everyday tasks and troubles which typically appear on traditional genre scenes portraying the life of Roma people.

The motif of the instrument hung upon the tree likely symbolized the pointlessness of art in Lenau's poem and in the artworks based on the poem. The Vanitas theme is one of the important philosophical meanings of the poem: the unnecessary, needless and senseless, painful scramble in life's 'market' contrasts the idea of another way of life, which is poor but free and balanced, based on Rousseau's idealistic beliefs about being closer to nature. The poem - according to literary history - is the lyrical description of the struggle between wanting to accomplish great deeds and the failure to achieve the set goals in the poet's soul, fought with a 'forced, resigned acceptance'. ${ }^{57}$

These artworks - just like Lenau's poem put to music by Ferenc Liszt - are proof of the Hungarian 


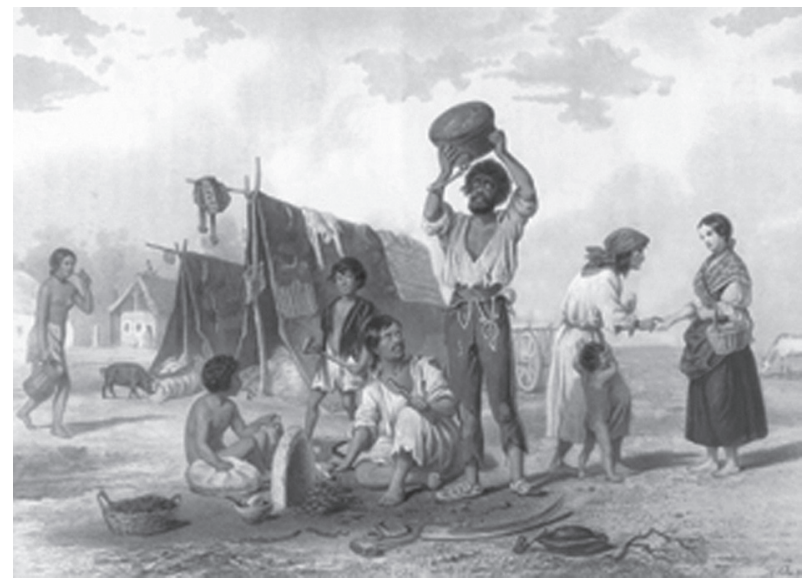

Fig. 14. Miklós Barabás: Zingaros nomade, coloured lithography, 1855

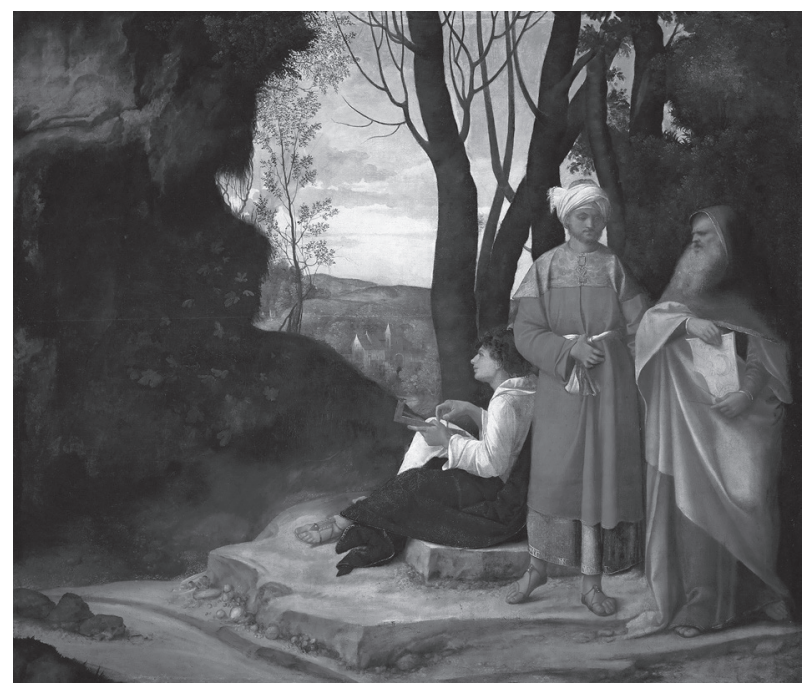

Fig. 15. Giorgione: The Three Philosophers, oil on canvas, 1508-1509; Vienna, Kunsthistorisches Museum

and Austrian popularity of not only The Three Gypsies poem, but also of the Austrian poet with a tragic life who sympathized deeply with Hungarians ${ }^{58}$ and was often inspired by the life of the people of Hungary. Schönn's choice of the theme, however - as demonstrated by other genre artworks of his depicting the life of Roma people ${ }^{59}$ - can also be a result of the intense ethnographical interest of several Austrian artists in the second half of the nineteenth century. One of these artists was August von Pettenkofen, ${ }^{60}$ who often vis-

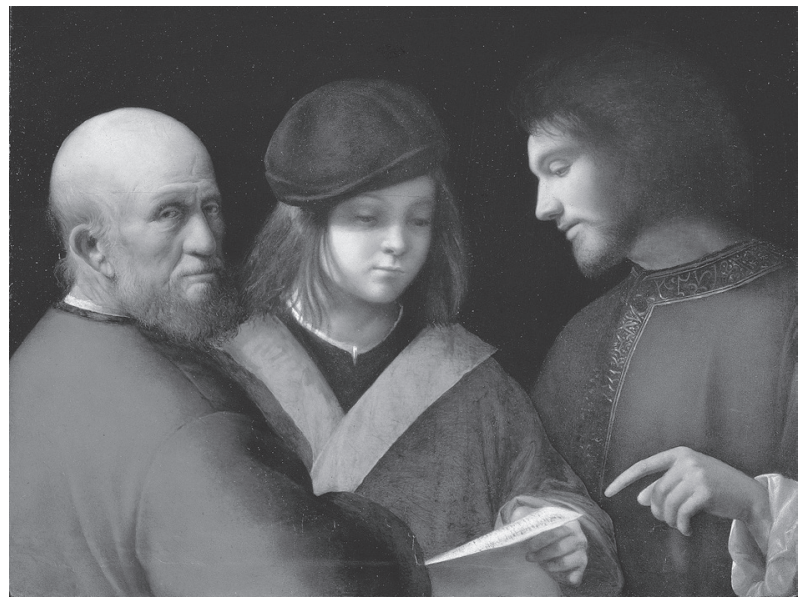

Fig. 16. Giorgione: The Three Ages of Man, oil on canvas, about 1500-1501, Florence, Palazzo Pitti (Galleria Palatina)

ited the town of Szolnok in the Great Hungarian Plain and even invited his Austrian painter friends to come with him. Pettenkofen turned in his artworks to the 'exotic' life of Hungarian peasants, horse-herdsmen and nomadic Roma people. ${ }^{61}$

The depiction of Roma people in literature and art was a romantic alternative to the Hungarian national characteristics in the nineteenth century. 'The amount of illustrated newspaper articles about the Roma people, for example, was much higher than the percentage of Roma people in society.' 62 These depictions showed not only the destitution and poverty of the Roma people, but also their longing for freedom, their independence and - related to their musicality - they also highlighted their artistic talent and self-expression, looking at them as positive role models. In the middle of the nineteenth century the depiction of Roma people in genre artworks in Hungary was mostly free of the negative stereotypes which appeared later, and their earlier mentioned romantic characteristics and 'picturesque' depiction made it possible for them to become part of the Hungarian national self-image. ${ }^{63}$ According to the Illustratio Hungariae, the Romani people ('the gypsy') became an inherent part of the image of Hungarian people in poetry, music and art - including, of course, the popular genres. ${ }^{64}$

\section{ABBREVIATIONS}

MNG

MNM

MNM TKCs
Magyar Nemzeti Galéria / Hungarian National Gallery, Budapest Magyar Nemzeti Múzeum / Hungarian National Museum, Budapest

Magyar Nemzeti Múzeum, Történeti Képcsarnok / Hungarian National Museum, Hungarian Historical Gallery, Budapest 


\section{BIBLIOGRAPHY}

BOetticher 1898 - BOetTicher, Friedrich von: Malerwerke des Neunzehnten Jahrhunderts, Beitrag zur Kunstgeschichte, Dresden, 1898. II/2.

CsokOnAi 1992 - Csokonai, Vitéz Mihály: Költemények 3. 1794-1796 [Poems 3. 1794-1796], prepared for publication, prefaced and completed with notes by SzILÁGYI, Ferenc, Budapest, 1992.

CsOmasz 1995 - CsOMAsz Tóth, Kálmán: Dicsérjétek az Urat! [Praise to the Lord!], Budapest, 1995.

IMRE 1994 - IMre, Mihály: A 79. zsoltár szerepe a Querela Hungariae toposz XVI. századi fejlódésében [The Role of Psalm 79 in the Development of the Trope of Querela Hungariae during the $16^{\text {th }}$ Century], Debrecen, 1994.

KovÁCS 2009 - KovÁCS, Éva: Fekete testek, fehér testek. A 'cigány' képe az 1850-es évektôl a XX. század elsô feléig [Black Bodies, White Bodies: The 'Gypsy' Image from the 1850s until the First Half of the 20 $0^{\text {th }}$ Century], Beszélô 14. 2009/1. 74-90.

Kraus 1978 - Kraus, Hans-Joachim: Psalmen (2. Teilband), Psalmen 60-150, in Biblischer Kommentar Altes Testament, begründet von NoTH, Martin, XV/2. Neukirchen, 1978. 1081-1086.

Liszt Ferenc 2011 - Liszt Ferenc és a 'czigány zene' A Néprajzi Múzeum kamarakiállítása 17. [Ferenc Liszt and the 'Gypsy Music'. A Small Exhibition of the Ethnographic Museum 17.], exhibition catalogue, Budapest: Néprajzi Múzeum, 2011.

Magyar zsoltár 1994 - Magyar zsoltár [Hungarian psalm], ed. Alexa, Károly, Budapest, 1994.

Mayr-Oenring 1997 - Orient. Österreichische Malerei zwischen 1848 und 1914, Hrsg. MAYR-OeHring, Erika, Katalog, Salzburg: Residenzgalerie, 1997.

Nemzet és mũvészet 2010 - XIX. Nemzet és múvészet. Kép és önkép [XIX. Nation and Art. Image and Self-Image], exhibition catalogue, eds. KIRÁly, Erzsébet - RóKA, Enikô - Veszzrémi, Nóra, Budapest: Magyar Nemzeti Galéria, 2010.

Oros-Klementisz 2008 - Oros-Klementisz, Marianna: Cigányok a képzőmûvészetben a vászon egyik és a másik oldalán [Roma People in Fine Arts on One Side of the Canvas and on the Another], Barátság 2008/3. 5716-5723. (http://nemzetisegek.hu/repertorium/2008/03/belivek_14-21.pdf 5716-5723.)
RÉVÉSz 2015 - RÉVÉSz, Emese: Kép, sajtó, történelem. Illusztrált sajtó Magyarországon 1850-1870 között [Image, Press, History. Illustrated Press in Hungary between 1850-1870], Budapest, 2015.

Roma E Sinti 2007 - Roma E Sinti. 'Zigeuner-Darstellungen' der Moderne, Hsgb. Baumgartner, Gerhard - Belgin, Tayfun, Katalog zur Ausstellung, Krems: Kunsthalle Krems, 2007.

RózsA 1978 - RózsA, György: Tóth Béla: A debreceni rézmetszô diákok. Könyvismertetés [The Copper Engraver Students of Debrecen. Book Review], Müvészettörténeti Értesítő XXVII. 1978. 106-109.

RózsA 1978/2 - RózsA, György: Nikolaus Lenau und die Kunst, Acta Historiae Artium XXIV. 1978. 387-390.

SCHAEFFER 1898 - SchaEFFER, August von: Alois Schönn Künstlerischer Nachlass, Wien, 1898. Ausstellung im Künstlerhause.

SCHAEFFER 1903 - SCHAEFFER, August von: Die Kaiserliche Gemälde-Galerie in Wien. Moderne Meister, Wien, 1903.

SCHAEFFER 1911 - SCHAEFFER, August von: Alois Schönn, Berichte und Mitteilungen des Altertums-Vereines zu Wien Band XLIV. Wien, 1911. 85-94.

Szinyei Merse 1990 - Szinyei Merse, Anna: Szinyei Merse Pál élete és müvészete [Life and art of Pál Szinyei Merse], Budapest, 1990.

SzŐ́lLôsy 2002 - SzólLôssy, Ágnes: Cigány a képen. Cigányábrázolás a XIX-XX. századi magyar képzômûvészetben [The Roma on Pictures. The Depiction of Roma People in Hungarian Fine Art in the $19-20^{\text {th }}$ Centuries], Beszéló 7. 2002/7-8. 72-81.

TAKÁCS 1986 - TAKÁCS, Béla: Bibliai jelképek a magyar református egyházmûvészetben [Biblical Symbols in Hungarian Calvinist Religious Art], Budapest, 1986.

Útirajzok 2001 - Útirajzok. Osztrák müvészek Magyarország tájain 1820-1880 [Travelogues. Austrian Artists in the Hungarian Countryside 1820-1880], exhibition catalogue, Budapest: Szépmúvészeti Múzeum, 2001.

WatzatKa 2014 - Watzatka, Ágnes: Puszta, Husaren und Zigeunermusik - Franz Liszt und das Heimatbild von Nikolaus Lenau, Studia Musicologica 55. 2014/1-2. 103-117.

WurzBACh 1876 - Biographisches Lexikon des Kaiserthums Oesterreich ...von Dr. Constant von WurzBach, Band 31, Wien, 1876.

\section{NOTES}

${ }^{1}$ Pirsig-Marshall, Tanja: Die Darstellung der Roma und Sinti anhand der 'Zigeunerikonographie' der klassischen Malerei, in Roma \& Sinti 2007, 11-14.

2 SZÓlLósSY 2002.

${ }^{3}$ Galavics, Géza: Johann Martin Stock und Joseph Haydn (Die Entdeckung der ungarländischen Zigeunermusiker im XVIII. Jahrhundert), Acta Historiae Artium 34. 1989/1-2. 245-252; Galavics, Géza: Johann Martin Stock (1742-1800): Gipsy Musicians in Hungary, in On the Stage of Europe. The Millennial Contribution of Hungary to the Idea of European Community, Budapest, 2009. 182-184.

${ }^{4}$ Papp, Júlia: Könyv és kép a 19. század elején. Blaschke János (1770-1833) illusztrációinak katalógusa [Book and Pic- ture in the Beginning of the $19^{\text {th }}$ Century. The Catalogue of the Illustrations of Johann Blaschke (1770-1833)], Budapest, 2012. I-II. 267-272.

${ }^{5}$ SzÓllôsy 2002, 73. See: Cigány-kép - Roma-kép. A Néprajzi Múzeum 'Romák Közép-és Kelet-Európában' címú nemzetközi kiállításának képeskönyve [The Image of the Gypsy - The Image of the Romani People. The Illustrated Book of the International Exhibition of the Ethnographic Museum Titled 'Roma People in Central and Eastern Europe'], ed. Szuhay, Péter, Budapest: Néprajzi Múzeum, 1998. 6-15; Nemzet és múvészet 2010, 279-280, 286-288. 
${ }^{6}$ BAumgartner, Gerhard - Kovács, Éva: Roma und Sinti im Blickfeld der Aufklärung und der bürgerlichen Gesellschaft, in Roma \& Sinti 2007, 15-23.

${ }^{7}$ A direct influence of Lenau's poem can be seen for example in the poem titled The Willow (Die Weide) written by Maximilian I, the Emperor of Mexico, who was executed in 1867.

8 Budapest, Magyar Nemzeti Galéria (Hungarian National Gallery), Inv. n.: F.K. 6733. Fürst, Leontin: Hangszerek a magyar képzômüvészetben [Musical Instruments in the Hungarian Fine Arts], Budapest, 1943. 42; Kopp, Jenô: Magyar biedermeier festészet [Hungarian Biedermeier Painting], Budapest, 1943. 14, 25; Fig. 9.

${ }^{9}$ The poem was published in 1838 in a book of Lenau's new poems titled Neuere Gedichte. About the poem and the description of earlier literature see: Huszar VARDAY, Agnes: Hungarian Influences in Lenau's Poetry, Buffalo, New York, 1974. 67-70.

10 RózSA 1978/2; Nikolaus Lenau, exhibition catalogue, Országos Széchényi Könyvtár, 1995. június 12. - július 30. The close relationship between Pongrácz's painting and the illustration in the newspaper Az Ország Tükre published in 1865 is highlighted in both studies. See also: Oros-KLEmENTISZ 2008.

11 WATZATKa 2014, 110-111.

12 Oros-Klementisz 2008, 5719.

${ }^{13}$ Az Ország Tükre 1865/30. 345. See: Révész 2015, 303.

14 GeRsZI, Teréz: A magyar kôrajzolás története a XIX. században [The History of Hungarian Lithography in the 19th Century], Budapest, 1961. 208. believes the artist is Mihály Szemlér. György Rózsa thinks the engraving is more similar to Lajos Elischer's works: RózSA 1978/2, 390.

${ }^{15}$ Vienna, Wienmuseum, inv. nr. 70595, oil, canvas. See: http://www.kunstrestitution.at/katalogdetailseite/katalog_oelmalerei.html?parent_katidIn:121\&perPageIn:1\&pag eIn:115

${ }^{16}$ Budapest, Nagyházi Gallery and Auction House. The reproduction of the painting and Lenau's poem can be found in VAjDA, György Mihály: Keletre nyílik Bécs kapuja. Közép-Európa kulturális képeskönyve 1740-1918 [The Gate of Vienna Opens to the East. The Cultural Picture Book of Central Europe 1740-1918], Budapest, 1994. 84. (Fig. 91)

17 Roma É Sinti 2007, 60, 61, 105, 106. See: KovÁcs 2009, 80, 90 (Footnote 33.)

${ }^{18}$ Liszt Ferenc 2011. 38, 39

${ }^{19}$ Budapest, Liszt Ferenc Zenemúvészeti Fôiskola Liszt Ferenc Múzeuma [The Franz Liszt Museum of the Franz Liszt Academy of Music], inv. nr. 86.858.

${ }^{20}$ WurZBACH 1876, 100.

21 ' 1 . 'Die drei Zigeuner' nach Lenau's gleichnamigen Gedichte. Lithographie von Alois Schönn in Wien, nach dessen Original-Oelgemälde.' (o.n.) '26. Schönn Alois in Wien. Die drei Zigeuner, nach Lenau's gleichnamigen Gedichte. (Das Vervielfältigungsrecht ist Eigenthum des österr. Kunstvereins.) fl. 500 Ö. W.' (o.n.): Verzeichniss und AusstellungKatalog der in den Monaten December 1858 bis Mai, dann im September 1859 für die am 29. d. M. stattfindende Verlosung angekauften Kunstwerke (Nietenblätter für 1859); see BOETTICHER 1898: 'Der Schläfer, Raucher u. Geiger, nach Lenau's Dichtung 'Die drei Zigeuner'. gr. fol. Oesterr. KV.-Bl. F. 1859.' 638; August Schaeffer refers to the oil painting as one of the artist's 'elite pictures' in his study written for the cata- logue of the exhibition of the artist's inheritance: SCHAEFFER 1898. The lithograph is mentioned by SCHAEFFER 1903, 84. See also PAPP, Júlia: Das Gemälde 'Die drei Zigeuner' von Alois Schönn, Wiener Geschichtsblätter 58. 2003/1. 55-61.

${ }^{22}$ About the life and art of SCHÖNn, Alois: Vincenti, Karl von, in Wiener Kunst-Renaissance, Wien, 1876. 320-344; HEVESI, Ludwig: Österreichische Kunst im neunzehnten Jahrhundert, Leipzig, 1903. 312; SCHAEFFER 1898, and SCHAEFFER 1903, 83-84; THIEME Ulrich - BECKER, Felix: Allgemeines Lexikon der bildenden Künstler von der Antike bis zur Gegenwart, Band XXX, 1936. 232; GRIMsChITZ, Bruno: Österreichische Maler vom Biedermeier zur Moderne, Wien, 1963. 26; FuCHS, Heinrich: Die österreichischen Maler des 19. Jahrhunderts, Wien, 1974. Band 4. 31, and Ergänzungsband 2. 105; Kunst des 19. Jahrhunderts, Bestandkatalog der Österreichischen Galerie in Wien, Band 4, Wien, 2000. 59-62; MAYROEHRING 1997, 220; Österreichisches Biographisches Lexikon 1815-1950, Wien, 1999. 90-91.

${ }^{23} \mathrm{E}$. g. The send-off of the company of Tyrolese students in the Südbahnhof in Vienna (Innsbruck, Ferdinandeum).

${ }^{24}$ The badge of the Order of Franz Joseph in 1873, the gold medal of the German Empire in 1874, the Chevalier (Knight) medal of the French Legion of Honour in 1878, and the medal of Archduke Karl Ludwig of Austria in 1882.

${ }^{25}$ MNM TKCs, inv. nr. T 1213. Lithograph by R. Hoffmann: 'Eine ungarische Familie kehrt nach Beendigung des Krieges in die Heimat zurück.' 1849. Angekauft vom Vereine für bild. Kunst. Lithogr. Von Dauthage. Im Jahre 1850 malte Schönn in Paris dieses Bild noch einmal, wo es von einem Grafen Morzin angekauft wurde.' SCHAEFFER 1911, 94. The events of the war of independence, such as the conscription, the caring for the wounded, the battle of Szolnok and, after József Borsos, the opening of the Hungarian parliament, was painted by the Austrian August von Pettenkofen, who was a war correspondent in Hungary in 1848 and 1849. See: Útirajzok 2001, 42.

${ }^{26}$ RózSAFFy, Dezsô: Osztrák múvészek Magyarországon [Austrian Artists in Hungary], Mũvészet 10. 1913. 336; About Austrian artists in the nineteenth century looking for 'oriental' themes in the Hungarian Plain see Sinkó, Katalin: Az Alföld és az alföldi pásztorok felfedezése a külföldi és a hazai képzőmúvészetben [The Discovery of the Plain and the Herdsman of the Plain in Foreign and Hungarian Fine Arts], Ethnographia 100. 1989/1-4. 121-154.

27 https://commons.wikimedia.org/wiki/File:Alois_

Sch\%C3\%B6nn_-_Lagernde_Zigeuner_(1856).jpg

${ }^{28}$ WURZBACH 1876, 100.

${ }^{29}$ MNM TKCs, inv. nr. T 5565. and T 8536.

30 Mayr-Oehring 1997, 220; MÉszáros, Ágnes: Aegypten. Reisebilder aus dem Orient. Hogyan kerültek Alois Schönn bécsi 'Orientmaler' festményei Libay Károly Lajos utazási albumának képtáblái közé? [How have Paintings by Alois Schönn, a Viennese Oriental Painter, Become Picture Tables in Karl Ludwig Libay's Travel Album?], Ars Hungarica 42. 2016/1. 33-42.

31 'Aus dieser Zeit stammt ein sehr bekanntes und beliebtes Bild 'Die drei Zigeuner' nach Lenaus Gedicht. Das Original blieb leider nicht in Wien, sondern wanderte nach Amerika, wogegen des Künstlers eigenhändige vortreffliche Litographie als Prämienblatt des damals noch in seiner Blüte stehenden österreichischen Kunst-vereines erschien und die weiteste Verbreitung fand.' SCHAEFFER 1911, 89. 
32 http://www.artnet.de/k\%C3\%BCnstler/alo\%C3\%AFssch\%C3\%B6nn/rast-der-zigeuner-kQfgRWpQFaEyR81GczgNQw2

33 Oil painting on glass: The catalogue of the Belvárosi Aukciósház (Belvárosi Auctionhouse) Budapest, May 2001, XVIII. art auction, item number 114. Emese Révész has brought the picture to my attention.

34 See: Liszt Ferenc 2011. 39; WatzatKa 2014, 112.

35 SZINYEI MERSE 1990, 27

36 SZINYEI MeRSE 1990, 27; Sketch of the Three Gypsies, about 1865, 296×220 mm, Budapest, MNG, inv. nr. 19282069/17; Three Gypsies, about 1866, $580 \times 480$ mm, Sabinov, Mestské Museum. See: Szinyei Merse 1990, 212.

37 Kraus 1978, 1081-1086; Ravasz, László: Ószövetségi magyarázatok [Explanations of the Old Testament], Budapest, 1993, 226; Jubileumi kommentár. A szentírás magyarázata [Jubilee Commentary. The Explanation of the Holy Scripture], Vol. II. Budapest, 1995. 631; SEYBold, Klaus: Die Psalmen, in Handbuch zum Alten Testament, I/15, Hrgb. KÖCKERT, Matthias - SMEND, Rudolf, Tübingen, 1996. 508-511.

${ }^{38}$ Ein Gott, eine Offenbarung. Beiträge zur biblischen Exegese, Theologie und Spiritualität. Festschrift für Nortker Füglister OSB zum 60. Geburtstag, Hrsg. ReITERER, Friedrich Vinzenz, Würzburg, 1991.; ROKAY, Zoltán: Secundum scripturas a 132. zsoltár hagyománytörténeti értékelése [Secundum scripturas - The Evaluation of the History of Traditions related to Psalm 132], in Az Apokalipszis. A Feltámadás. Biblikus konferencia 1991-1992 [The Apocalypse. The Resurrection. Biblical conference 1991-1992], ed. BENYIK, György. Szeged, 1993. 95-104; BRUEGGEMANN, Walter: Engedelmesség és istendicséret: Zsoltár és kánon [Obedience and Praising God: Psalm and Canon], in '...mert örökké tart szeretete.' Tanulmányok Dr. Karasszon Dezsố tiszteletére 70. születésnapja alkalmából ['...His Love Endures Forever.' Studies in the Honour of Dr. Dezsô Karasszon for the Occasion of His $70^{\text {th }}$ Birthday], Budapest, 1994. 5-34; TóтH, Kálmán: Régi magyar zsoltárfordítások Kinizsi Pálné Magyar Benigna imádságos könyvében (1513) [Old Hungarian Psalm Translations in the Prayer Book of Benigna Magyar, Wife of Pál Kinizsi], in ibid. 169-187; Sulyok, Elemér: A 22. zsoltár. Istenem, miért hagytál el engem? (Zsoltárkommentár) [Psalm 22. My God, My God, Why have You Forsaken Me? (Commentary on the Psalm)], Pannonhalma, 1998 (Pannonhalmi kisfüzetek 8.); ZENGER, Erich: The Composition of the Book of Psalms, Leuven-Paris-Walpol, 2010; NÉMETH, Áron: 'Királyok zsoltára, zsoltárok királya' A 72. zsoltár előállása és teológiája a Zsoltárok könyve redakciójának tükrében ['Psalm of Kings, King of Psalms' The Inception and the Theology of Psalm 72 in Light of the Redaction of the Book of Psalms], Doctoral dissertation (PhD), Debreceni Egyetem [Debrecen University], Debrecen, 2015.

${ }^{39}$ Magyar zsoltár 1994; ImRe 1994; PetrốcZI, Éva: Miért sebzett olykor a 42. zsoltár szomjú szarvasa? [Why is the Thirsty Deer of Psalm 42 Sometimes Wounded?], in Jankovics József 50. születésnapjára [Essays in Honour of József Jankovics on His Fiftieth Birthday], Budapest, 1999. 28-29.

${ }^{40}$ Motívumkutatás és mítoszkritika. Komparatisztikai tanulmányok [Study of Motifs and Mythological Criticism. Comparative Studies], ed. Goretity, József, Debrecen, 1998; SzABó, Júlia: A mitikus és a történeti táj [The Mythical and the Historical Landscape], Budapest, 2000. 7-8.
${ }^{41}$ Csizmadia, Károly: Bibliai eredetû szállóigék, szólásmondások, közmondások [Proverbs, Sayings and Idioms of Biblical Origins], Gyôr, 1987. 74-75; TAKÁcs 1986, 106107; Csomasz 1995, 77; According to more recent interpretations, the first lines of the psalm do not describe a specific event: they are the ritual lament of the captured Jewish community remembering the destruction of Jerusalem. KRAUS 1978, 1083-1084.

42 One copy is in the collection of engravings found in the inheritance of Alajos Györgyi Griegl. I wish to thank Magdolna Lindner for the chance to study the collection.

43 'The specific content of Psalm 79 makes it possible for artists to use it bravely in hard, cruel historical circumstances to talk about their current situation and to treat it almost as a pretense/excuse to write the sorrowful laments of their own era.' IMRE 1994, 39.

${ }^{44}$ Magyar zsoltár 1994, 499; Just like János Sylvester's paraphrase of Psalm 79 from 1544, where the humanist poet wrote about the tragic situation in Hungary in an addition placed between the lines of Psalm 79, which is a lament about the destroyed temple in Jerusalem: Janus Pannonius - Magyarországi humanisták [Hungarian humanists], sel. Klaniczay, Tibor, Budapest, 1982. 358-359. See: PAPP, Júlia: Rom és rekonstrukció. (Hazai építészeti emlékek 19. századi ábrázolásairól) [Ruin and Reconstruction. (Of the $19^{\text {th }}$ Century Depictions of Hungarian Architectural Relics)], in Tanulmányok Rózsa György tiszteletére [Essays in Honour of György Rózsa], Budapest: Magyar Nemzeti Múzeum, 2005. 121-133.

45 CsOKOnai 1992, 749.

${ }^{46}$ Csokonai 1992, 156-157.

${ }^{47}$ András Farkas: A Lói Tanáts zabolázója, about 1830, etching and engraving. See: RózsA 1978, 109. (Fig. 6.); Múvészet Magyarországon 1780-1830 [The Arts in Hungary 1780-1830], eds. Szabolcsi, Hedvig - Galavics, Géza, Budapest, 1980. 229 (Kat. 178); Fig. 70/178; KNAPP, Éva: 'A Lói Tanáts Zabolázója' ['The Curber of the Council of 'Lo')], in Berei Farkas András vándorköltố élete és munkássága (1770-1832) [Life and Profession of the Wanderer-Poet András Berei Farkas], Vol. 1. Zebegény, 2007. 236-238; ibid. Vol. 2.: Berei Farkas András munkáinak bibliográfiája [The Bibliography of the Works by András Berei Farkas], Zebegény, 2007. 185.

${ }^{48}$ Magyar zsoltár 1994, 578.

${ }^{49}$ Magyar zsoltár 1994, 579.

50 VeZÉr, Erzsébet: Ady Endre élete és pályája [Life and Profession of Endre Ady], Budapest, 1977². 247.

${ }^{51}$ Scholars of biblical hermeneutics have different opinions on whether the word in the original text of the psalm means willow or poplar (The Interpreter's Bible, Vol. IV. Abindden, Nashville, 1980. 705). According to an earlier lexicon of the Bible, the original Hebrew word in the psalm means Babylonian poplar (Bibliai Lexikon [Biblical Encyclopaedia], eds. CzEglédy, Sándor - Hamar, István - DR. Kállay, Kálmán, Budapest, 1931. 389). Hungarian literary tradition, however, uses a willow since the very beginning, just like the more recently published Christian lexicon of the Bible (Keresztyén bibliai lexikon, ed. Dr. Bartha, Tibor, Budapest, 1995. Vol. II. 276). Either way, in Linnaeus's taxonomy the Latin name of the weeping willow is from Psalm 137: Salix Babilonica. See also: TAKÁCS 1986, 106. Though 
Csokonai's previously mentioned poem mentions an elder tree instead of a willow - as revealed in his other poems, to him this tree is the symbol of bad, worthless poetry -, the motif is clearly related to Psalm 137. CsOKONAI 1992, 753.

52 Property of the MKB Bank (Hungarian Foreign Trade Bank), in the custody of the MNG. Before its reappearance in 1991 the only sources about the painting were Sándor Petôfi's poem titled A Life of Wandering and a short story written by Ignác Nagy about the Roma family on the painting: Nemzet és múvészet 2010, 292; WatZATKA 2014, 110.

53 http://mek.oszk.hu/12100/12104/12104.pdf

54 Oros-Klementisz 2008, 5719.

55 Giorgione: The Three Philosophers, oil on canvas, 15081509, Vienna, Kunsthistorisches Museum.

${ }^{56}$ Giorgione: The Three Ages of Man, oil on canvas, circa 1500-1501, Florence, Palazzo Pitti (Galleria Palatina).

${ }^{57}$ MÁDL, Antal: Írók történelmi sorsfordulókon [Writers during Fateful Moments of History], Budapest, 1979. 84.

${ }_{58}$ His The Three Gypsies poem appeared in the book published in Vienna to aid the victims of the great Danube flood of 1838 in Hungary: Album... zum Besten der Verunglückten in Pesth und Ofen, Wien, 1838. 155.
59 BOETTICHER 1898, 637-638.

60 Útirajzok 2001, 42-45.

${ }^{61}$ See also VeszprÉmi, Nóra: Barabás Miklós, Petőfi Sándor és az utazó cigánycsalád. Egy közös motívum a 19. századi magyar képzômúvészetben és irodalomban [Miklós Barabás, Sándor Petôfi and the Traveling Roma Family. A Common Motif in Hungarian Fine Art and Literature in the $19^{\text {th }}$ Century], Mưvészettörténeti Értesítô LI. 2002/3-4. 284; RÉvÉsz, Emese: A népéletkép szerepe a nemzeti jellem hazai kidolgozásában az 1850-1870 közötti hazai sajtóillusztráció példáján [The Role of Folk Genre Pictures in the Making of the National Character, Based on the Example of Hungarian Printed Press Illustrations between 1850 and 1870], Ars Hungarica 32. 2004/2. 314; RÉVÉsz, Emese: Nemzeti identitás a 19. századi populáris grafikában [National Identity in the Popular Graphics of the $19^{\text {th }}$ Century], in Nemzet és mûvészet 2010, 197; RÉvÉSZ 2015, 297-304.

62 RÉVÉsz 2015, 297.

63 RÉVÉSz 2015, 297-303.

${ }^{64}$ Kovács 2009, 79-80. 